\title{
Desinența de plural -le și interferențe între morfologia flexionară și cea derivațională
}

\author{
Blanca Croitor* \\ Institutul de Lingvistică „Iorgu Iordan - Al. Rosetti”, Calea 13 Septembrie 13, 050711 București, România
}

\begin{tabular}{|c|c|}
\hline Despre articol & Rezumat \\
\hline $\begin{array}{l}\text { Istoric: } \\
\text { Primit } 24 \text { mai } 2017 \\
\text { Acceptat } 4 \text { iulie } 2017 \\
\text { Publicat } 30 \text { septembrie } 2017 \\
\text { Cuvinte-cheie: } \\
\text { morfologie flexionară } \\
\text { morfologie derivațională } \\
\text { desinența -le } \\
\text { sufixul -ale } \\
\text { sufixul -ele }\end{array}$ & $\begin{array}{l}\text { În articol sînt descrise situațiile în care desinența de plural -le are valoare deriva- } \\
\text { tivă, de formare a unor substantive la plural, de genul feminin. Ea face parte din } \\
\text { două sufixe cu care se derivă substantive la plural, -ale și -ele (ambele cu sufixe } \\
\text { dezvoltate). În unele formații împrumutate sufixele au fost atașate etimonului } \\
\text { pentru a le încadra în sistemul morfologic românesc, iar alte formații au fost } \\
\text { create în limba română. Unele formații neologice cu -ale au fost împrumutate, } \\
\text { fiind analizabile în română. Sînt inventariate formațiile cu aceste sufixe (și cu } \\
\text { cele dezvoltate), în principal pe baza DA, DLR, DI și MDA. În articol se fac și } \\
\text { observații privind vechimea sufixelor și a formațiilor, productivitatea, raportul } \\
\text { cu eventualele forme de singular (acolo unde existăa și sînt descrise cîteva aspecte } \\
\text { teoretice. }\end{array}$ \\
\hline
\end{tabular}

\section{Introducere}

În acest articol, vom arăta că desinența de plural (feminin) -le are uneori și o valoare lexicală, de derivare a unor formații cu formă de plural, cu sens de singular sau de plural. Desinența de plural -le este moștenită din latină, în substantive de tipul cățea - cățele, măsea - măsele, stea - stele (pentru acest tip morfologic, v. Graur, 1961). Ea a fost întărită în sistemul morfologic ca semn al pluralului prin împrumuturi, majoritatea din turcă (basma - basmale, cercevea - cercevele, cişmea - cişmele, duşumea - dușumele, manea manele, merdenea - merdenele, rindea - rindele, teșcherea - teșcherele, sarma - sarmale), dar și din limbi slave (manta - mantale), din limbi romanice (bretea - bretele, jaluzea - jaluzele, pijama - pijamale), din neogreacă (cucuvea - cucuvele, frigănea - frigănele), din maghiară (reg. cheşchenea - cheșchenele „năframă, batistă”) sau cu origine multiplă (canapea - canapele, din neogreacă, franceză și germană). Constatăm că sînt două tipuri de împrumuturi, terminate în $-e \boldsymbol{a}$ (mai numeroase) sau în $-\boldsymbol{a}$. De asemenea, poziția desinenței de plural a fost întărită prin numeroase creații interne cu sufixul diminutival (ca valoare principală) - ea și cu diverse sufixe complexe (dezvoltate sau compuse cu ea): cea, icea, ucea, ulea, -unea, -uşea, -uţea, -ițea, -oțea (v. Pană Dindelegan, 2007). Cu valoare lexicală, desinența (afixul) -le se identifică în sufixele -ale, - ele și cîteva sufixe dezvoltate de la acestea două, cu care se derivă substantive cu formă de plural, majoritatea de genul feminin.

\section{Sufixele - ale și -icale}

Sufixul -ale are origine multiplă (v. FCLR, p. 122-123): (a) a fost creat în română, pentru adaptarea unor împrumuturi din neogreacă cu final neobișuit pentru sistemul morfologic românesc, terminate la plural

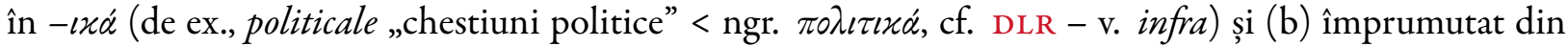
latină $\left(-\right.$ ales $\left.^{1}\right)$, din franceză (-ales) și din germană (-alien), prin intermediul unor substantive analizabile.

\footnotetext{
*Adresă de corespondență: ileanablanca@gmail.com.

${ }^{1}$ Lat. -ales reprezintă forma de plural a sufixului adjectival -alis.
} 
Substantivele analizabile cu sens de plural împrumutate din neogreacă se terminau în -lxá, un final neobişnuit pentru substantivele românești, care nu fac pluralul în $-a$. Ataşarea desinenței de plural le a încadrat aceste substantive în sistemul morfologic românesc. În limba actuală, ele sînt substantive feminine pluralia tantum ${ }^{2}$, analizabile prin raportare la sufixele -ale și-icale (dezvoltat din -ale, v. FCLR,

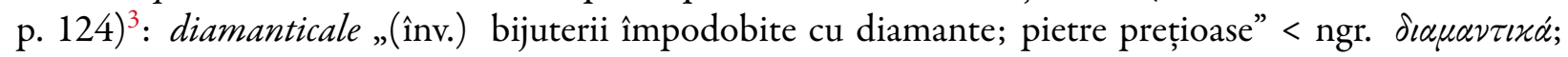

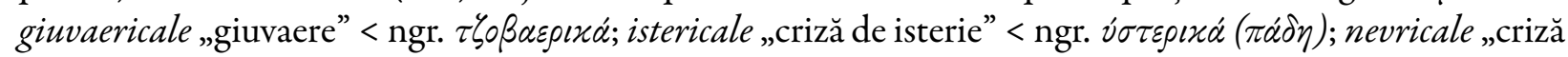

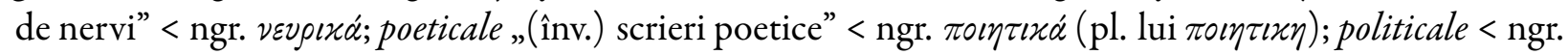
$\pi 0 \lambda \iota \tau \imath x \alpha$; revmaticale „reumatism” < ngr. $\rho \varepsilon v \mu \alpha \tau \iota x \alpha$; tipicale „cîntări pentru anumite servicii religioase” < ngr. $\tau v \pi i x \dot{\alpha}$ (dar DLRM îl dă din tipic); triadicale „cele 12 tropare treimice care încep cu «cuvine-se [sau: cade-se] cu adevărat », care se cîntă pe ehul II, după canonul troișnic - la miezanoptica duminicii” (DTM) < ngr. $\tau \rho \iota \alpha \delta \iota x \dot{\alpha} \tau \rho \circ \pi \alpha ́ \rho \iota \alpha$; vasilicale „compilație grecească a dreptului roman, începută de împăratul Vasile I

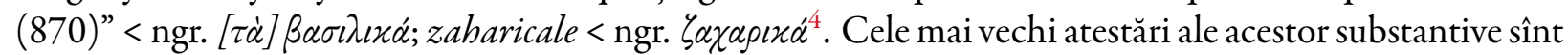
de la sfirșitul secolului al XVIII-lea, cu forma neadaptată la sistemul morfologic românesc (cea terminată în -a): giuvaerica este atestat în 1792 (apud șIO, în DA, într-un context din care nu reiese dacă are înțeles de singular sau de plural: Giuvaericà, mărgăritar i ceasornic), iar zaharica este atestat în 1794 (la Iorga, S.D. VIII, 29, în DLR, cu sens de plural: O bucătăriță săsoaică... care să aibă știință și pracsis de uscături, de bucate și de zaharica). În secolul următor, se înregistrează primele atestări ale formațiilor adaptate, cu -le: zabricale (atestat în 1814, la Dionisie, C. 187, cf. DLR, s.v. zaharica); vasilicale (atestat în 1817, în Uricariul IV, 302/20, cf. DLR); revmaticale (la Piscupescu, O. 297/2, în DLR); diamanticale (atestat în 1831, în CR 42/34, cf. DLR); istericale (la Gorjan, H. II, 123, în DA); poeticale (la Alecsandri, S. 44, în DLR); giuvaericale (la Filimon, apud TDRG, cf. DA); politicale (în Conv. Lit. III, 98, în DLR); nevricale (la Vlahuță, O. A. 149, în DLR). În această perioadă se constată și conturarea unei opoziții între sg. în -a și pl. în -ale, de ex. giuvaerica vs. giuvaericale: [...] pronunțînd cu îngîmfare numele fiecărei mătăsării sau giuvaerica, [...] lăsînd să se vadă cît se putea mai bine o cutie de giuvaericale (N. Filimon, Ciocoii vechi și noi). Cîteva împrumuturi au primele atestări în sec. al XX-lea și al XXI-lea: tipicale (în TDRG, cf. DLR), triadicale (în DTM).

A doua sursă a sufixului -ale în română au fost împrumuturile analizabile din latină, franceză și germană terminate în forme ale acestui sufix. Primele împrumuturi sînt de pe la mijlocul secolului al XIXlea: anale (în Uricariul V, 155/6, cf. DA) „scriere istorică în care sînt înregistrate an cu an întîmplările importante din viața unui popor; publicație științifică anuală” < lat. annales, fr. annales; saturnale (în Calendar (1858) 48/18, cf. DLR) „sărbătoare populară la romani, în cinstea zeului Saturn, care avea loc în fiecare an după terminarea muncilor agricole” < fr. saturnales. Mai multe împrumuturi sînt recente: actinomicetale „ordin de bacterii ramificate, amintind de ciuperci” < fr. actinomycétales (MDN); aspergilale „ordin de ciuperci ascomicete: mucegaiurile (aspergilul, penicilium etc.)” < fr. aspergillales (MDN); chimicale "nume generic dat produselor chimice” < germ. Chemikalien $\left(\mathrm{DEX}_{2}\right)$; mirtale „ordin de plante cu flori, cu numeroase familii, printre care mirtaceele” < fr. myrtales (MDN); piperale „ordin de plante cu flori: piperaceele și familiile înrudite" < fr. pipérales $(\mathrm{MDN})^{5}$.

Din împrumuturile analizabile cu finala -ale, substantive de genul feminin, numărul plural, s-a detașat un sufix -ale folosit pentru a crea pe teren românesc substantive pluralia tantum (de genul feminin), îndeosebi regionale sau populare: burtucale, ,intestine de animal” (atestat în Rev. Crit. III 91, cf. DA, s.v. bu$r d u f)$, cf. burtuc „burtuş; mațele din vită”; trancanale „vorbe goale; lucruri casnice mărunte, îngrămădite

\footnotetext{
${ }^{2}$ Pentru unele substantive au apărut mai tîrziu și forme de singular în -ală, puțin folosite. Astfel, pentru zaharicale a apărut o formă de singular saharicală (forma cu $z$ - nu este atestată), întîlnită doar în dicționare (Polizu, Pontbriant, D. 645, cf. DLR, s.v. zaharica).

${ }^{3}$ Sursele formațiilor inventariate sînt DA și DLR sau cele indicate între paranteze.

${ }^{4}$ Unele substantive de acest tip, împrumutate din neogreacă sau din turcă, nu sînt analizabile: geamparale „castaniete; tril

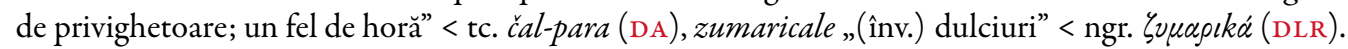

${ }^{5}$ Putem menționa aici și formația coloniale, învechită astăzi, care reprezintă o adaptare după germ. Kolonialwaren „mărfuri din colonii” (DA, MDA), posibil și din fr. [denrées] coloniales ( $\left.\mathrm{DEX}_{2}\right)$. În (FCLR, p. 120), se arată că formația poate proveni și din substantivarea adjectivului la fem.pl., desprins din sintagma mărfuri coloniale, deci nu ar fi un derivat.
} 
sau în dezordine” (prima atestare la Pann, P. V. III, 95/8, cf. DLR, s.v. trancana), cf. (a) trăncăni și tranc (în raport cu care s-ar detașa un sufix dezvoltat -anale); turtale „(reg.) un fel de prăjituri făcute la sărbătorile mari” (în Chest. V 8/5, cf. DLR), cf. turtă; vrîstale „(reg.) dungi (într-o țesătură)” (Vîrcol, M. 88, Gr. Băn., în DLR), cf. vîrstă „dungă, bandă de altă culoare”; zăngănele „accesorii la modă care fac zgomot” (internet), cf. (a) zăngăni; zdrancanale „(reg.) obiecte casnice mărunte (care zdrăngăne)” (la Udrescu, Gl., cf. DLR, s.v. zdrancana), cf. (a) zdrăncăni; zdrăngănele „accesorii (de purtat la gît) de dimensiuni mai mari, care zdrăngăne” (internet), cf. (a) zdrăngăni; zorzonale „(reg.) podoabe pretențioase, lipsite de valoare" (în Mat. Folk. 353, în DLR, s.v. zorzoană), cf. zorzon, zorzoană. În limba standard, cu acest sufix $s$-a creat substantivul cosmeticale ( $\left.\mathrm{DEX}_{2}\right)$.

Putem adăuga la acest inventar și formații semianalizabile, precum hartapale „bucăți rupte, zdrențuite” (Muscel, 111, în DA, s.v. hartan), cf. harta-parta „rupt în bucăți” și hartan „bucată (mare) de carne; bucată ruptă din ceva”; zangarale „(Olt.) zorzoane; podoabe de nichel și de alamă aplicate pe hamuri” (atestat la Ciaușanu, Gl., Coman, Gl., cf. DLR, s.v. zangara).

Se poate observa că există o dublă repartiție stilistică a formațiilor cu -ale: unele sînt din registrul standard sau din limbajele de specialitate, altele sînt populare sau regionale. Această separație ișsi are cauzele în originea multiplă a sufixului: internă, prin convertirea desinenței de plural -le în afix lexical derivativ (detașată împreună cu finala - $a$ sau -ica), și externă, detașată din împrumuturi neologice analizabile, de circulație literară. Formațiile cu -icale sînt din categoria celor de circulație regională sau populară. Ambele sufixe au fost slab productive pe teren românesc, iar în limba actuală nu se înregistrează formații noi.

\section{Sufixul-ele}

Sufixul nominal -ele nu este discutat în literatura de specialitate consultată ${ }^{6}$, probabil pentru că a fost considerat o simplă formă de plural a sufixului cu formă de feminin $-e a^{7}$. De altfel, și în dicționare formațiile cu -ele sînt uneori indicate ca formate cu sufixul -ea, deși exemplele indicate sînt doar cu forma de plural (de exemplu: adormițele - în DLRM; alunele - în DA; ațîţele - în MDA; găluştele - în MDA etc.), alteori ca formate cu sufixul -ele (adormițele - în $\mathrm{MDA}$; fărîmele - în $\mathrm{DEX}_{2}$; măgurele, piersecele, scălcele, sclipurele, spetele, stenurele, strîmturele - toate în DLR etc.). Uneori, dicționarele indică derivarea cu sufixul -el (masculin), deși toate exemplele sînt cu forma plural în -ele (sfaturele, sesurele, stucurele - în DLR). Cel mai probabil, sufixul - ele provine din forma de plural a sufixului diminutival moștenit $-e a$, fiind desprins din formațiile analizabile cu forma de plural a acestui sufix. El a devenit destul de productiv, ducînd la formarea unor substantive pluralia tantum cu sens diminutival atenuat sau chiar fără sens diminutival. Faptul că sufixul - ele se atașează și unor teme verbale este un semn că acesta și-a pierdut sensul diminutival inițial.

Indicăm mai jos un inventar al formațiilor analizabile cu sufixul -ele, care se pot raporta la baze substantivale, adjectivale sau verbale (este vorba de raportarea semantică, nu de etimologie), întocmit pe baza DI, DA, DLR, MDA și DLRLC. Majoritatea sînt substantive de genul feminin, excepțiile (de genul neutru) sînt indicate mai jos:

(a) cu baze nominale: alunele „1. (bot., reg.) numele mai multor plante; 2. pistrui” (cf. alun); bănuțele „(bot.) planta cunoscută și sub numele de bănuței” (bănuţ „idem”); cîmpurele n. „cîmpuri mici” (cf. cîmpuri); colțurele n. „(pop.) colțuri mici” (cf. colțuri); cornurele n. „colțișoare” (cf. cornuri); fărîmele „fărîme mici” (cf. fărîmă); găluștele „găluște mici” (cf. găluşcă); găurele „fel de broderie pe o pînză din care s-au scos cîteva fire pentru a obține un spațiu rărit, pe care apoi se coase; ajur" (DLRLC) (cf. gaură); gogoșele „diminutiv al lui gogoaşă - diverse obiecte rotunde și goale pe dinăuntru” (cf. gogoaşă);

\footnotetext{
${ }^{6}$ Urmează a fi tratat în partea a doua a volumului Formarea cuvintelor în limba română. IV. Derivarea nominală şi adverbială, realizat la Institutul de Lingvistică „Iorgu Iordan - Al. Rosetti” din București (v. FCLR - prima parte).

${ }^{7}$ Sufixul -el (fem. -ea) provine din lat. - ellus (fem. -ella) și a fost moștenit în cuvinte precum cățel, cățea < catellus, respectiv catella; vițel, vițea < vitellus, respectiv vitella, derivatele cu acest sufix fiind atestate înainte de sec. al XVI-lea (PopescuMarin, 2007, p. 86).
} 
măgurele „(reg.) diminutiv hipocoristic al lui măgură”; nemurele n. „(Mold.) neamuri; diminutiv al lui neam” (cf. neamuri); nodurele n. „(reg.) diminutiv al lui noduri”; pacișele / păcişele „fire de in sau de cînepă de calitate inferioară, care rămîn în piepteni în timpul operație de pieptănare a fuiorului" (cf. pacişă „idem”); păcurele „turme mici de oi, animale, vite” (cf. păcure „turmă de oi, animale, vite”); păltinele „(bot.) coacăz(e)” (cf. păltinel „coacăz”); păsuiele „(bot., Banat, Trans.) salcîm” (cf. păsui „fasole”); păștele „(bot., reg.) flămînzică” (cf. paști „pîine sfințită”); păturele f. „pătuțuri” (cf. paturi); pîjele n. „pîjuri” (cf. pîj „,cui de lemn cu care se fixează obezile”); penele „(Mold.) fîșii de tei din care se fac funii” (cf. pană „piesă de lemn întrebuințată la despicarea lemnelor”); piersecele „(Olt.) planta „papucul-domnișoarei” (cf. piersică); ploiele „(reg.) alice mai mari decît ploaia” (cf. ploaie); pomițele „(reg.) căpșun” (cf. pomiță); prînzurele n. (cf. prînz); prezenturele n. „mici cadouri” (cf. prezent „(înv.) cadou, dar”); prundurele f. „(pop.) diminutiv al lui prunduri” (cf. prunduri); pudărele „(reg., Hațeg) podoabe” (cf. pudră, în DLR); răchițele „arbust tîrîtor pitic, cu flori roz-carmin, care crește în regiunile muntoase” (cf. răchită); răcorele / răcărele „nume dat unor plante erbacee agățătoare (volbură, zorele, respectiv zorele bătute - în forma răcărele)” (cf. răcoare); sămurele f. „samuri mici” (cf. sam „tiv la poalele hainelor”); săpunele - denumirea unor plante: "plantă ornamentală cu flori albastre și frunze lanceolate; dumitraș; flori-de-toamnă; scînteiuțe” (cf. săpun); scălcele „(reg.) coada-zmeului; păpădie” (cf. scalce „plantă erbacee toxică, cu frunze în forma copitei de cal și cu flori mari, galbene-aurii”); schimburele f. diminutiv al lui schimburi; sclipurele n. „bolți mici” (cf. sclipuri, pl. lui sclip „boltă, arcadă”); sfaturele n. în sintagma a face sfaturele „a gîngăvi” (cf. sfaturi); spetele „(reg.) platcă (la cămășile bărbătești)” (cf. spete, pl. de la spată); stenurele f. „(pop.) stînci mici” (cf. stean, var. lui stană „bolovan, bloc mare de piatră”); strîmturele „(Bucov.) obiect de îmbrăcăminte pentru femei” (cf. strîmturi, pl. de la strîmtură); șesurele n. „(pop.) șesuri mici” (cf. șesuri); soimele "șoimane” (cf. șoim); ștucurele n. „bucățele, fragmențele” (cf. ștucuri, pl. de la ștuc „fragment, bucată”); șușele / susele „(Mold., Bucov.) șipci bătute pe pereții sau pe tavanele de lemn ca să se prindă muruiala” (cf. şuşă); tătărcele „(bot., reg.) rostopască” (cf. tătarcă, denumirea mai multor plante); tulpănele n. „(Bucov.) numele unor floricele nedefinite mai îndeaproape" (cf. tulpan); țundrele (DI) (cf. țundră „(Trans., Banat) haină țărănească largă și lungă, făcută din dimie de culoarea naturală a lînii”); vinețele 1 „(înv.) vinișoare" (cf. vînă (DLR), în raport cu care s-ar detașa un sufix dezvoltat -ețele, și vinețiu); vîrstele „(reg.) dungi de altă culoare decît cea a fondului (într-o țesătură)” (cf. vîrstă „dungă, bandă de altă culoare”); zorele „numele mai multor plante” (cf. zori).

În general, formațiile derivate de la teme substantivale de genul neutru, la plural, cu desinența -uri, sînt de genul neutru (cimpurele, colţurele, cornurele, nemurele, nodurele, prînzurele, prezenturele, prundurele, sclipurele, sfaturele, șesurele, ștucurele). Este posibil ca încadrarea la neutru din dicționar să se fi făcut prin analogie cu baza. Unele formații cu baze de genul neutru au fost încadrate în DLR la genul feminin: păturele, sămurele, schimburele, stenurele.

(b) cu baze verbale: acățele „(bot.) cîrcei la vița de vie” (cf. (a) acăța, var. de la (a) agăța); adormițele „(bot.) dediței” (cf. adormit); ațițtele „(Trans.) surcele” (MDA) (cf. (a) ațiţta); bodrogănele „(înv.) discuții; ciorovăieli” (MDA) (cf. (a) bodrogăni, var. lui (a) bodogăni); ghionghionele „(turcism) maniere afectate spre a plăcea” (DA) (cf. (a) ghionghioni); măgulele „faptul de a măguli” (cf. (a) măguli); păcănele ${ }_{1}$ „(Munt.) cele două brațe de la războiul de țesut, ale căror capete sînt legate de cîte o iță, iar mijlocul de prăjină” (cf. (a) păcăni); păcănele „(arg.) pocher electronic; jocuri mecanice” (Volceanov $)^{8}$; picățele „1. desen format din puncte mici dispuse pe un fond de altă culoare; 2 . (reg.) minciunele” (cf. picat); pupățele „(Bucov.) pupături” (cf. pupat); spărgele „(reg.) nume de plantă; vălul-miresei” (cf. (a) sparge); toconele „(Olt.) numele unei melodii tradiționale” (cf. (a) toconi, o variantă neatestată a lui (a) tocăni; DLR trimite pentru etimologie la tocăliță); țîşnele „(reg.) un soi de prune" (cf. (a) țîsni).

${ }^{8}$ Este destul de puțin probabil capăcănele 2 să fie legat (etimologic) de păcănele 1 , cel mai probabil e vorba de cuvinte diferite, păcănele 2 fiind o creație recentă, colocvială (pentru o discuție despre această formație, v. Zafiu, 2013). 
(c) cu baze adjectivale (mai rar): flocoșele „(bot.) diferite specii de plante păroase” (cf. flocos); gălbenele „denumirea mai multor tipuri de plante” (cf. galben); iuțele „(reg.) legume iuți, ardei, castraveț”” (cf. iute); rumenele / romănele „fard roșu” (cf. rumen); sărbezele „strugurii-ursului” (cf. sarbăd); vinețele „numele mai multor plante” (cf. vînăt); zăluzele (DI) (cf. zălud; în DLR este menționat doar subst. zăluzeală, cu pl. zăluzeli).

(d) cu bază onomatopeică: șoșele, în expresia (a umbla) cu șoşele (și cu momele) „(a umbla) cu făgăduieli mincinoase, cu înșelătorii” (cf. şoşo(șo), prin analogie cu momele).

Unele formații substantivale sînt analizabile printr-un sufix dezvoltat: drăgănele (împrumutat din sb. draganela, draganlija, cf. DLR, s.v. drăgănel, -ea) este analizabil prin drag și suf. -ănele; perițele „(reg.) scrîntitoare” se analizează prin (a) pieri (DLR) și suf. -ițele; perteluşele „(reg.) îmbrăcămintea ușorului” este format de la perdea (DLR) și -(e)luşele; pietrucele "garofițe de grădină; arșinic" este format din piatră + suf. -ucele (DLR); prescurărele „(bot., Trans.) urechelniță” este format din prescură și -ărele (DLR); rototele / rotoțele „(bot., reg.) bănuț” este format de la roată (DLR) cu -otele/-oțele; sălbănele „(Trans.) sălbănașe, tip de cusătură cu care se împodobesc mînecile cămășii la portul popular” este format din salbă (DLR) cu -ănele; ursărele „(bot., Bucov.) brumărele; garofițe de grădină”, format de la urs cu -ărele (DLR).

Cîteva formaţii sînt semianalizabile: hîrjele, utilizat în expresia a grăi în hîrjele „a grăi în ponturi, în figuri și alegorii; a face glume” (cf. hîrjeate „tăblițe de joc”, în DA); paipanele „(Olt.) catalige, picioroange” (DLR), cf. paipanoage, var. de la papainoage „idem”; popdele „smirdar”, cf. podbal (DLR); săftiele „piele subțire și fină folosită pentru confecționarea articolelor de marochinărie și de galanterie” (DLR), cf. saftian „idem”; strambele „(Munt.) toane, capricii”, cf. strambițe „idem” (DLR); paraiele, utilizat în sintagma luat din paraiele „paralizat”, este semianalizabil prin para- „foarte tare, puternic” și suf. -iele $e^{9}$

În inventarul formațiilor cu sufixul -ele, am întîlnit și o formație adjectivală (folosită la feminin, numărul plural): borețele „(reg.) pline de lapte” (atestat în ALRT II, 60/9), derivat din borețe, adjectiv cu acelaşi sens (conform MDA; cuvîntul nu este indicat în DA).

Formațiile de mai sus sînt substantive la plural, care fie nu au un corespondent la singular (în -ea sau în $-\boldsymbol{e l}$, pentru cele neutre), fie au un corespondent la singular dar cu alt sens, fie au și o formă de singular care este atestată în sursele consultate ulterior formei de plural (deci putem presupune că singularul este refăcut de la plural, care reprezintă un derivat cu -ele). Astfel, în sursele consultate (în primul rînd DA, DLR, dar și MDA, DEX 2 ), sînt înregistrate și substantivele la singular (cu sens diferit de substantivul la plural, cu -ele): măturea „mătură mică”; ocheșea „diminutiv hipocoristic al lui oacheș”; pupezea „pupăză mică"; scrijea „felie de pîine”; secerea „seceră mică”; uscățea „diminutiv al lui uscat”; vinețea ,albăstrea” ș.a. Din cauza diferențelor de sens, nu se poate considera că formația terminată în -ele reprezintă o formă de plural a substantivului la singular, deci trebuie analizate separat, ca formații cu sufixul -ele. Dacă alături de formația terminată în - ele există și substantivul la singular, în -ea, cu acelaşi sens și cu atestări aproximativ din aceeași perioadă, se poate considera că formația în -ele reprezintă forma de plural a substantivului în $-e a$, nu un derivat aparte. Delimitările sînt uneori greu de făcut, atestările din dicționare fiind puține.

Se cuvine să avem în vedere și o serie de substantive împrumutate din alte limbi la care s-a adăugat în română desinența - le ca marcă a pluralului, pentru a le integra în sistemul morfologic românesc (o situație

\footnotetext{
${ }^{9} \mathrm{O}$ serie de substantive feminine la plural terminate în -ele, cu sens de singular sau de plural, întîlnite în DI și DLR, nu sînt analizabile. Multe dintre ele figurează cu etimologie necunoscută, la altele se face trimitere la alte cuvinte. Deși nu le putem considera derivate cu sufixul -ele, le menționăm deoarece întăresc acest tipar morfologic în română: arvele „(înv.) conuri de brad” (DA); befele „(bot.; reg.) nu-mă-uita” (MDA); bibițele „(reg.) afaceri mărunte” (MDA); bomborele „(reg.) grăunțe” (MDA); borodele „(reg.) fructe puse la fermentat pentru țuică” (MDA); căruțele „(bot., reg.) pătlagină îngustă” (MDA; nu se poate analiza semantic prin căruță); chistosele „(Trans.) piftie”; crepenele în sintagma în crepenele „(reg.) de-a berbeleacul” (MDA); didinele „(bot., reg.) pejmă” (DLR); gîgîțele „(bot.) dediței; brîndușă” (DA); hodrobele „(Trans.) bagaj, lucruri trebuincioase la drum” (DA); miţuvele „brîndușă de primăvară” (DLR); ochinpele / ochincele „ghințură; degetariță” (DLR); pandele „(bot., reg.) numele unei specii de prune” (DLR); păşunele „(reg.) pacișă” (DLR); posincele „(Banat) făină de grîu de calitate inferioară; tărițe” (DLR); prichidele „(reg.) nume dat unor părți ale căruței” (DLR); rocodele / rogodele „(pop.) fructe (mărunte), poame de tot felul” (DLR); solele „(reg.) crini galbeni” (DLR); tarapangele „(reg.) legume, zarzavaturi” (DLR); vinturele „dediței” (DLR; nu se poate analiza semantic prin vînturi); zamfirele „(Mold.) crupe” (DLR; nu se poate analiza prin zamfir, variantă de la safir).
} 
asemănătoare cu cea descrisă mai sus, la împrumuturile la care s-a adăugat -ale: diamanticale, giuvaericale, istericale, nevricale, poeticale, politicale, revmaticale, tipicale, triadicale, vasilicale). Ele sînt substantive la plural, fără un corespondent la singular în română (pluralia tantum). Sub aspect morfologic, acest proces poate fi considerat unul derivativ, nu flexionar, deoarece nu există opoziția între o formă de singular și una de plural: fesfesele „(Mold.) zorzoane, nimicuri care fac parte din dichisurile femeiești” < tc. fesfese (DA); ghionghionele "(turcism) maniere afectate spre a plăcea; fasoane, mofturi” < tc. ğüna-ğün „fel de fel; de orice fel” (DA; de la substantiv s-a creat în română verbul (a) ghionghioni); lovele „(arg.) bani” < țig. lové (m.pl., de la sg. lovo); mezele "mezeluri” < tc. meze (DLR, Scriban); sacamele „(reg.) fleacuri, nimicuri”, cf. tc. șaka „glumă” (DLR); țipele „(Trans., Banat) pantofi; ghete; țipici” < magh. cipello", cf. și scr. cipela (cu formele de singular refăcute după plural țipeauă, țipel, în DLR).

După cum se poate observa, sufixul - ele a fost productiv în limba română, la nivelul limbii populare şi regional. Temele la care s-a atașat acest sufix (sau cele dezvoltate) au fost de origini diverse:

- moștenite: acățele, adormițele, alunele, ațîțele, cîmpurele, cornurele, gălbenele, găurele, nodurele, păcurele, păștele, penele, perițele, piersecele, pietrucele, ploiele, prînzurele, pupărele, rotoțele, sălbănele, săpunele (dar și prin neogreacă), secerele, spărgele, spetele, șesurele, ursărele, uscățele, vinețele ${ }_{1}$, vinețele

- create în română: bănuțele, crepenele, duruiele, flocoșele, ocheșele, păcănele 1 , păcănele, păltinele, picățele, pomițele, răcorele, scălcele, schimburele, strîmturele, șoșele, tătărcele, toconele, țișnele, zăngănele, zdrăngănele;

- slave: colțurele, găluștele, iuțele, măgulele, păcișele, pîjele, popdele, prescurărele, prundurele, răchițele, rumenele, sclipurele, scrijele, sfaturele, stenurele, vîrstele, zăluzele, zorele;

- din neogreacă: păsuiele, păturele, tulpănele;

- turcești: ghionghionele;

- latino-romanice: prezenturele, pudărele;

- maghiare: nemurele, soimele;

- nemțești: sămurele, ștucurele;

- din substrat (probabil): fărîmele, măgurele, pupezele;

- cu etimologie necunoscută: bodrogănele, borețele, măturele, sărbezele, șuşele/susele, țundrele.

În limba actuală sufixul este slab productiv, înregistrîndu-se puține formații noi (v. păcănele 2 , zăngănele, zdrăngănele).

\section{Concluzii}

Am arătat că desinența -le este folosită și cu valoare derivativă, în sufixele -ale și -ele (pentru -ale, v. FCLR), precum și în cîteva sufixe dezvoltate de la acestea două, în mai multe tipuri de formații:

- formaţii la care s-a atașat desinența - le pentru a încadra substantivul în sistemul flexionar românesc, etimonul avind o finală neobișuită pentru română;

- formații create în limba română cu sufixele -ale și - ele (și cele dezvoltate), de la teme de diverse origini;

- împrumuturi din limbile latino-romanice sau din germană (doar cu sufixul -ale).

Formațiile cu aceste sufixe sînt în general substantive pluralia tantum, de genul feminin (cu cîteva excepții, încadrate la genul neutru în DLR, prin analogie cu baza). Unele dintre ele au şi forme de singular, refăcute din forma de plural (singularul avînd atestări ulterioare pluralului). Altele au alt sens decît corespondentul cu formă de singular (de multe ori, și sens de singular), deci nu pot fi considerate forme de plural (iar -le trebuie analizat ca afix derivativ, nu flexionar). La formațiile cu sens de plural, afixul le cumulează valoarea derivativă și pe cea flexionară, similar sufixului moțional $-\breve{a}$, care are și valoare desinențială (exprimînd genul și numărul) sau desinenței - uri atașate la substantivele masive, determinînd schimbări de sens (v. Pană Dindelegan, 2017; Maiden, 2014), inclusiv la substantive de genul feminin. 


\section{Bibliografie}

DA = Dicționarul limbii române (sub conducerea lui Sextil Pușcariu). Tomul I. Partea I. $A-B$, Librăriile Socec \& Comp. și C. Sfetea, București, 1913; Tomul I. Partea II. C, Tipografia Ziarului „Universul”, București, 1940; Tomul I. Partea III. Fascicula I. D-De, „Universul”, Intreprindere Industrială a Statului, București, 1949; [Fascicula II. De-Desțina; șpalt, 1948]; Tomul II. Partea I. F-I, Monitorul Oficial și Imprimeriile Statului. Imprimeria Naţională, București, 1934; Tomul II. Partea II. Fascicula I. J-Lacustru, Tipografia Ziarului „Universul” S.A., București, 1937; Tomul II. Partea II. Fascicula II. Ladă-Lepăda, Tipografia Ziarului „Universul” S.A., București, 1940; Tomul II. Partea II. Fascicula III. Lepăda-Lojniță, Tipografia Ziarului „Universul” S.A., București, 1948.

$\mathrm{DCR}_{2}=$ Dimitrescu, F. (1997). Dicționar de cuvinte recente, ediția a II-a, Editura Logos, București.

$\mathrm{DEX}_{2}=$ Dicționarul explicativ al limbii române (conducătorii lucrării: acad. Ion Coteanu, dr. Luiza Seche, dr. Mircea Seche),

Editura Univers Enciclopedic, București, 1998; ediția a II-a, revizuită și adăugită, Editura Univers Enciclopedic Gold, București, 2009.

DI = Dicţionar invers, Editura Academiei, [București], 1957.

DLR = Dicționarul limbii române. Serie nouă (redactori responsabili: acad. Iorgu Iordan, acad. Alexandru Graur şi acad.

Ion Coteanu. Din anul 2000, redactori responsabili: acad. Marius Sala și acad. Gheorghe Mihăilă), Editura Academiei, București. Tomul I. Partea a 3-a. Litera D (D-Deînmulțit), 2006; Tomul I. Partea a 4-a. Litera D (Deja-Deținere), 2006; Tomul I. Partea a 5-a. Litera D (Deținut-Discopotiriu), 2007; Tomul I. Partea a 6-a. Litera D (Discord-Dyke), 2009; Tomul I. Partea a 7-a. Litera E (E-Erzaț), 2009; Tomul I. Partea a 8-a. Litera $E$ (Es-Ezredeş), 2010; Tomul III. Literele J, K, Q, 2010; Tomul IV. Litera L (L-Lherzolită), 2008; Tomul V. Litera L (Li-Luzulă), 2008; Tomul VI. Litera M, 1965-1968; Tomul VII. Partea 1. Litera N, 1971; Tomul VII. Partea a 2-a. Litera $O$, 1969; Tomul VIII. Partea 1. Litera P (P-Păzui), 1972; Tomul VIII. Partea a 2-a. Litera P (Pe-Pînar), 1974; Tomul VIII. Partea a 3-a. Litera P (Pînă-Pogrilanie), 1977 ; Tomul VIII. Partea a 4-a. Litera P (Pogrijanie-Presimțire), 1980; Tomul VIII. Partea a 5-a. Litera P (Presin-Puzzolană), 1984; Tomul IX. Litera R, 1975; Tomul X. Partea 1. Litera $S$ (S-Sclabuc), 1986; Tomul X. Partea a 2-a. Litera $S$ (ScladăSemînţărie), 1987; Tomul X. Partea a 3-a. Litera S (Semn-Sîveică), 1990; Tomul X. Partea a 4-a. Litera S (Slab-Sponghios), 1992; Tomul X. Partea a 5-a. Litera S (Spongiar-Swing), 1994; Tomul XI. Partea 1. Litera S, 1978; Tomul XI. Partea a 2-a. Litera T (T-Tocăliță), 1982; Tomul XI. Partea a 3-a. Litera T (Tocăna-Twist), 1983; Tomul XII. Partea I. Litera Ț, 1994; Tomul XII. Partea a 2-a. Litera $U, 2002$; Tomul XIII. Partea 1. Litera $V$ (V-Veni), 1997; Tomul XIII. Partea a 2-a. Litera $V$ (Venial-Vizurină), 2002; Tomul XIII. Partea a 3-a. Litera $V$ (Vìclă-Vuzum) și Literele $W, X, Y, 2005$; Tomul XIV. Litera $Z, 2000$.

DLRLC = Dicționarul limbii române literare contemporane (sub direcția prof. univ. Dimitrie Macrea și acad. Emil Petrovici). Volumul I: $A-C, 1955$; volumul al II-lea: $D-L, 1956$; volumul al III-lea: $M-R, 1957$; volumul al IV-lea: $S-Z, 1958$, Editura Academiei, [București].

DLRM = Dicționarul limbii române moderne (sub direcția prof. univ. D. Macrea), Editura Academiei, [București], 1958.

DTM = Fircă, Gh. (coordonator științific), Alexandrescu, L. M., Grigorescu, O. \& Suceava, D. (redactori coordonatori) (2010). Dicționar de termeni muzicali, ed. a III-a revăzută și adăugită, Academia Română, Institutul de Istoria Artei, Editura Enciclopedică Gold, București.

FCLR = Sala, M. (coord.) (2015). Formarea cuvintelor în limba română. Vol. al IV-lea. Sufixele. Derivarea nominalăși adverbială, Partea 1, Editura Academiei Române, București.

Graur, Al. (1961). Din istoricul tipului stea / stele, în „Studii de gramatică”, vol. al III-lea, red. resp. Al. Graur, Jacques Byck, Editura Academiei Române, București, p. 5-9.

Maiden, M. (2014). Le rôle de la synonymie lexicale dans formation du pluriel flexionnel en daco-roman, în "Mémoires de la Société de Linguistique de Paris. Série tome XXII. Morphologie flexionnelle et dialectologie romane: typologie(s) et modélisation(s)", Peeters Publishers, p. 35-50.

MDA = Micul dicționar academic, 4 vol. (redactori responsabili: Acad. Marius Sala și Ion Dănăilă; lucrarea a fost începută sub conducerea Acad. Ion Coteanu), Editura Univers Enciclopedic, București. Volumul I: $A-C$ (2001); volumul al II-lea: $D-H$ (2002); volumul al III-lea: $I-\operatorname{Pr}$ (2003); volumul al IV-lea: $\operatorname{Pr}-Z$ (2003).

MDN = Marcu, F. (2002). Marele dicționar de neologisme, ediție revizuită, augmentată și actualizată, Editura Saeculum I.O., București.

Pană Dindelegan, G. (2007). Reflecții pe marginea a două tipare flexionare nominale: (ea/a) Ø - -le vs u/ŭ/Ø - -uri, în Reinheimer Rîpeanu, S. \& Vintilă-Rădulescu, I. (eds), Limba română, limbă romanică, Editura Academiei Române, București, p. 425-434.

Pană Dindelegan, G. (2017). Substantive masive și abstracte pluralizate în româna veche, în „Diacronia”, nr. 6, 30 sept., art. A82, Crossref.

Popescu-Marin, M. (coord.) (2007). Formarea cuvintelor în limba română din secolele al XVI-lea - al XVIII-lea, Editura Academiei Române, București, 2007.

Zafiu, R. (2013). Păcănele, în „Dilema veche”, nr. 504, 10-16 octombrie 2013, [online]. 